[Bull. Agr. Chem. Soc. Japan, Vol. 24, No. 6, p. 629 630, 1960]

\title{
Muta-aspergillic Acid, A New Growth Inhibitant against Hiochi-bacteria
}

Sir ;

In the previous paper ${ }^{13}$, the author isolated hydroxyaspergillic acid, $\mathrm{G}_{12} \mathrm{H}_{20} \mathrm{~N}_{2} \mathrm{O}_{3}$, m.p. 152 $3^{\circ} \mathrm{C}$, from the culture filtrate of Aspergillus oryzae as a growth inhibitant against hiochibacteria.

From the pre-analysis material of this acid, the author, recently, has succeeded to isolate the other new growth inhibitant against hiochi-bacteria by counter current distribution between ethyl acetate and Sörensen's $N / 10$ citrate buffer solution $(\mathrm{pH}$ 6.2) in a yield of about one percent.

The author proposes to designate this antibiotic as muta-aspergillic acid.

Muta-aspergillic acid was recrystallised as a pale yellow needle from aqueous alcohol. It is readily soluble in most organic solvent, and slightly soluble in ether, $n$-hexane and hot water, but insoluble in petroleum ether and ligroin. It melts at $173 \sim 4^{\circ} \mathrm{C}$ (uncorr.)(decomposed and sublimes), and is optically inactive. $[\alpha]_{D}^{25}=0 \pm 0.3^{\circ} \quad \mathrm{c}=3.5$ in methanol). Anal. Found; C 57.67, H 8.44, N 12.25, O 21.64\%, M.W. 246 (determined by Rast method) Calcd. for $\mathrm{C}_{11} \mathrm{H}_{18} \mathrm{~N}_{2} \mathrm{O}_{3} ; \mathrm{C} 58.39, \mathrm{H} 8.02, \mathrm{~N} 12.38, \mathrm{O}$ 21.21\%, M.W. 236. Kuhn-Roth C-methyl determination gave 1.9 moles of acetic acid per mole. Ultra-violet absorption in methyl alcohol shows the 2 bands, $\lambda_{\max } 242 \mathrm{~m} \mu$ ( $\varepsilon=$ $5140)$ and $\lambda_{\max } 335 \mathrm{~m} \mu(\varepsilon=8571)$ and $\mathrm{pKa}$ value of 4.8 was measured. Ninhydrin and ferric chloride reactions were both positive. It formed emerald green cupric salt melting at $231^{\circ} \mathrm{C}$.

These properties and infrared spectrum shown in Fig. 1 suggest that this antibiotic

1) S. Nakamura and T. Shiro, Bull. Agr. Chem. Soc. Japan, 23, 65 (1959). belongs to the group of aspergillic, hydroxyaspergillic $^{2-4)}$, and neohydroxyaspergillic ${ }^{\text {s) }}$ acids, which have the same basic structure of cyclic hydroxamic acid. However, the molecular formula of muta-aspergillic acid was found to be less one methylene group than hydroxyaspergillic acid.

Muta-aspergillic acid was converted to 2,5diketopiperazine compound $\mathrm{C}_{11} \mathrm{H}_{20} \mathrm{~N}_{2} \mathrm{O}_{2}$, (V) through monobromo compound, m.p. $113^{\circ} \mathrm{C}$, (IV) by the route shown in the following figure, and this compound (V) was degraded to leucine and valine by hydrolysis with hydrochloric acid.

These results provided evidence that mutaaspergillic acid has the two side chain, isobutyl and isopropyl in its molecule.

Group analyses show the presence of one hydroxy (mono acetyl derivative, m.p. $111^{\circ} \mathrm{C}$ ) and one n-hydroxy (Cu-salt, m.p. $231^{\circ} \mathrm{C}$ and $\mathrm{FeCl}_{3}$ reaction).

Infrared spectrum of this antibiotic shows the same absorption band, at $1120^{-1} \mathrm{~cm}$, as hydroxyaspergillic acid. It has been well established, in general, that tertiary alcohol has a $\mathrm{C}-\mathrm{O}$ band at about $1150^{-1} \mathrm{~cm}$ and this band is shifted about $-30^{-1} \mathrm{~cm}$ to longer wave length when $\alpha$ carbon to tertiary alcohol has the branch.

Moreover, as descrived above, this antibiotic is optically inactive and does not form any iodoform on treatment with hypoiodite.

These facts provide evidence that the hydroxy group of this antibiotic is tertiary and locates at the isopropyl side chaine.

\footnotetext{
2) J.D. Durcher, J. Biol. Chem., 171, 321, 341 (1947); 232, 785 (1958).

3) G. Dunn, J.J. Gallagher, G.T. Newbold and F.S. Spring, J. Cbem. Soc., S. 126 (1949).

4) G. Dunn, G.T. Newbold and F.S. Spring, J. Chem. Sor., S. 131 (1949); 2679 (1951).

5) U. Weiss, F. Strelitz, H. Flow and I.N. Asheshov, Arch. Biopbys., 74, 150 (1959).
} 


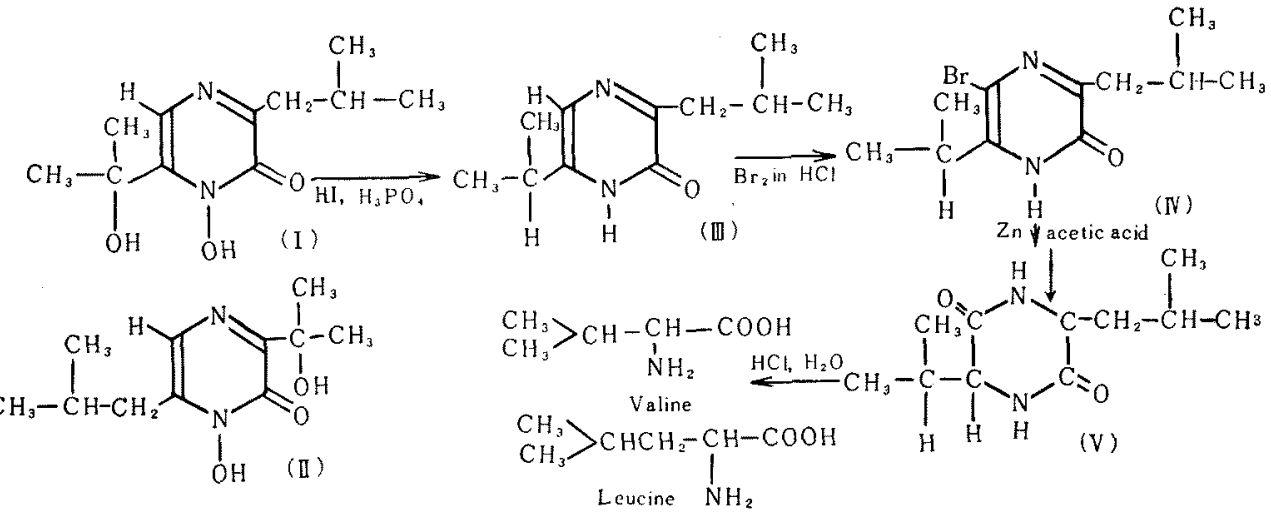

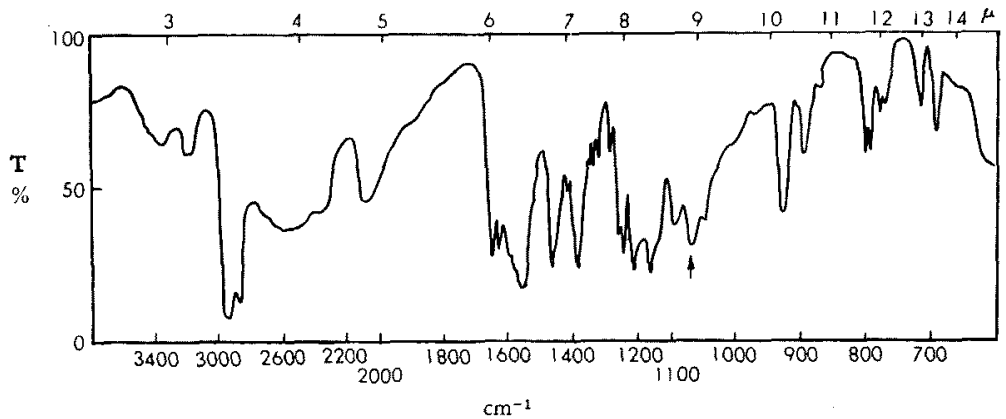

FIG. 1. Infrared Spectrum of Muta-aspergillic Acid (Nujol mull)

The above mentioned results lead to draw the conclusion that formula (I) or (II) is the most possible structure for this antibiotic.

The minimum concentration for complete inhibition of growth in a diluted Sake-peptone medium (composed of 70 parts of Sake, 30 parts of water and 1 part of polypeptone) against true hiochi-bacilli (Lactobacillus homohiochii H-42 and Lactobacillus heterohiochii $\mathrm{H}-1$ ) was $5 \sim 10 \mathrm{meg} / \mathrm{ml}$, and that against hiochilactobacilli ( $\mathrm{H}-7$ and $\mathrm{H}-34$ ) $10 \sim 20 \mathrm{meg} / \mathrm{ml}$.

At higher concentrations, it did not inhibit the growth of Bacillus subtilis, Staphylococcus aureus, Proteus bulgaris, Mycobacterium phlei, Mycobacterium 607, Penicillium chrysogenum, Aspergillus niger, Candida albicans, Saccharomyces cereviciae, Tolura ntilis, Corynebacterium xerosis.
$\mathrm{LD}_{50}$ for mice administrated intraperitoneally was $100 \mathrm{mg}$ per $\mathrm{Kg}$ of body weight.

The author expresses his sincere thanks to Prof. Y. Sumiki, University of Tokyo for his guidance and encouragement throughout the course of this work and to Emeritus Prof. K. Sakaguchi and Prof. H. Umezawa for their sound advices and also to Mr. T. Shiro, Yamamura Sake-brewing laboratory and $\mathrm{Mr}$. Y. Kurimura, Central Research Laboratory Sanraku Distillers Co. LTD. for their cordial assistances in this work.

Seiji NAKamura

Institute of Applied Microbiology

The University of Tokyo

Bunkyo-ku, Tokyo, Japan

Received August 13, 1960 